\title{
Biochar Amendment Associated to Compost and/or Iron in Order to Improve Lead and Arsenic Soil Stabilization and Salix Viminalis Growth
}

\author{
Manhattan Lebrun ${ }^{1,2}$, Florie Miard², Romain Nandillon², Dalila Trupiano ${ }^{1}$, Elena De Zio1, Gabriella S. \\ Scippa $^{1}$, Sylvain Bourgerie ${ }^{2}$, Domenico Morabito ${ }^{2}$ \\ ${ }^{1}$ Università degli Studi del Molise \\ Contrada Fonte Lappone, Pesche, Italy \\ manhattan.lebrun@etu.univ-orleans.fr; dalila.trupiano@unimol.it; elena.dezio@studenti.unimol.it; scippa@unimol.it \\ ${ }^{2}$ University of Orleans, INRA USC1328, LBLGC EA 1207 \\ rue de Chartres, BP 6759, 45067, Orléans Cedex 2, France \\ florie.miard@univ-orleans.fr; romain.nandillon@iddea-ingenierie.fr; sylvain.bourgerie@univ-orleans.fr; \\ domenico.morabito@univ-orleans.fr
}

\section{Extended Abstract}

More than one million of sites are potentially contaminated in Europe, mostly by metal(loid)s [1]. Such soil pollution constitutes a major problem, as it is a threat to both the environment and the human health. Therefore, polluted areas need to be remediate. Phytoremediation, the use of plants and associated microorganisms to reduce the contaminants risks, is a technique chosen nowadays over chemical and physical ones since it is an environmental friendly and cost-effective solution [2]. Phytoremediation process relies on the establishment of a plant cover that will stabilize the soil and prevent wind erosion and water leaching. Moreover, the plants will take up the contaminants and store them in their tissues. Salix viminalis, a woody species, has shown potential in phytoremediation. Indeed, it is characterized by (i) high biomass production, (ii) deep and wide root system, (iii) high capacity to tolerate and accumulate metal(loid)s [3]. However, contaminated soil conditions being extremes, amendment application is recommended in order to permit plant establishment.

Among amendments, biochar, a carbonaceous product obtained from the pyrolysis of biomass under low oxygen conditions, was shown as a good soil conditioner to ameliorate soil fertility, thus to promote plant growth [4]. Additionally to biochar, compost also has been demonstrated to improve soil conditions; this product is formed through microbial degradation, it is rich in humic substances, microorganisms and inorganic components [5]. However, both biochar and compost showed efficient sorption capacities towards metal cations but not to metal anions [6]. This can be problematic in the case of multi-contaminated soils. A solution is to use Fe based amendments, like iron grit, whose oxidation after soil incorporation will provide sorption surfaces for both metal cations and anions [7].

The objectives of the study were to evaluate, with a focus on the rhizosphere area, the effects of biochar, compost and iron grit, applied alone or combined, on the: (i) soil physico-chemical properties, (ii) Salix viminalis growth and metal(loid)s accumulation/tolerance, (iii) soil metal(loid)s stabilization.

A mesocosm experiment was set up, using a former mine technosol, located in Pontgibaud (France) amended with biochar (5\%), compost (5\%) and iron grit (1.5\%), alone or in combination, and non-rooted cuttings of Salix viminalis grown for 69 days in greenhouse conditions.

The soil pore water and soil analyses showed an improvement of the soil physico-chemical properties following amendment addition, i.e $\mathrm{pH}$ and electrical conductivity increases together with a decrease of $\mathrm{Pb}$ concentrations. Such ameliorations led to a better plant growth, except in the case of the iron amendment, alone and in combination with biochar, which can be attributed to a too high application dose. In addition, plant root enzyme activities rose in the case of biochar and/or compost amendments. It was also observed that metal(loid)s were mainly accumulated in the roots with low translocation towards aerial organs, which demonstrated the phytostabilization potential of Salix viminalis plants. Moreover proteomic profiles were analyzed to better understand the mechanisms/network associated to plant metal(loid)s accumulation and/or stabilization. Finally, based on those results, we will define the best amendment or combination for future large-scale stabilization of metal(loid)s contaminated areas, using Salix viminalis. 


\section{References}

[1] P. Panagos, M. Van Liedekerke, Y. Yigini, L. Montanarella, "Contaminated sites in Europe: review of the current situation based on data collected through a European network," J. of Environmental and Public Health, Article ID 158764 , pp. 11, 2013.

[2] H. Ali, E. Khan, M Sajah, "Phytoremediation of heavy metals - Concepts and applications," Chemosphere, vol. 91, pp. 869-881, 2013.

[3] M. Lebrun, F. Miard, R. Nandillon, J-C. Léger, N. Hattab-Hambli, G.S. Scippa, S. Bourgerie, D. Morabito, “Assisted phytostabilization of a multicontaminated mine technosol using biochar amendment: early stage evaluation of biochar feedstock and particle size effects on As and $\mathrm{Pb}$ accumulation of two Salicaceae species (Salix viminalis and Populus euramericana)," Chemosphere, vol. 194, pp. 316-326, 2018.

[4] J. Paz-Ferreiro, H. Lu, S. Fu, A. Méndez, G. Gascó, "Use of phytoremediation and biochar to remediate heavy metals polluted soils: a review," Solid Earth, vol. 5, pp. 65-75, 2014.

[5] P. Madejon, J. Xiong, F. Cabrera, E. Madejon, "Quality of trace element contaminated soils amended with compost under fast growing tree Paulownia fortunei plantation," J. of Environmental Management, vol. 144, pp. 176-185, 2014.

[6] L. Beesley, O. Inneh, G Norton, E. Moreno-Jimenez, T. Pardo, R. Clemente, J. Dawson, "Assessing the influence of compost and biochar amendments on the mobility and toxicity of metals and arsenic in a naturally contaminated mine soil," Environmental Pollution, vol. 186, pp. 195-202, 2014.

[7] J. Kumpiene, S. Ore, G. Renella, M. Mench, A. Lagerkvist, C. Maurice, "Assessement of zerovalent iron for stabilization of chromium, copper and arsenic in soil," Environmental Pollution, vol. 144, p. 62-69, 2006. 